ORIGINAL ARTICLE

\title{
Examination of Physıcal Educatıon Teacher's Opinions on Effective Class Management
}

\author{
AHMET YIKILMAZ 1 , FIKRET ALINCAK ${ }^{2}$ \\ ${ }^{1}$ Iğdır University School of Physical Education and Sports \\ ${ }^{2}$ Gaziantep University Faculty of Sports Sciences \\ Correspondence: Dr. Ahmet YIKILMAZ, Email: yikilmazahmett@gmail.com, Contact:05057304889
}

\begin{abstract}
Background: In order for education and training to be successful, various factors in the educational environment must be known, regulated and well managed. Classroom management enables teachers to carry out their teaching tasks effectively. In order to manage the classroom, teachers must have classroom management skills. A teacher who does not have classroom management skills will have difficulty in classroom management and failure in education is inevitable.

Aims: The aim of this study is to reveal the views of physical education teacher candidates on effective classroom management. The research is a qualitative study. The research group consists of 10 physical education teacher candidates and this study group was determined by the maximum diversity sampling method.

Place \& duration of study: In the research, face-to-face interview technique was used in accordance with the voluntary basis and studying at Iğdır University School of Physical Education and Sports.

Method: In the research, using the interview method, which is one of the qualitative research methods, the data obtained were analyzed by the content analysis method.

Results: As a result of the research, physical education teacher candidates stated that for an effective classroom management, teachers should be competent in their field and love their profession. The physical education teacher candidates participating in the research came to the forefront by endearing the lesson and the teacher. In addition, the research group; They stated that they would motivate students in classroom management by giving responsibility to the student, determining the classroom rules together with the student, and applying different teaching methods. In addition, in order for the student-teacher communication of the research group to be effective; They expressed their opinion that a democratic environment should be created and cooperation between the parties should be ensured.

Conclusion: In addition, in terms of improving the classroom management skills of the research group; In addition to gaining professional skills and practice skills, while managing unwanted student behaviors in the classroom; They stated that it is necessary to give responsibility to the student and to plan the lesson together with the student. At the same time, for an effective classroom management; It has been concluded that an effective classroom management can be done by knowing the student well and establishing healthy communication with the student.

Keywords: Physical Education, Teacher Candidate, Classroom Management.
\end{abstract}

\section{INTRODUCTION}

The school is defined as the most important part of the education system, the concrete organization that determines the operational boundaries and its environment and aims at production at the first level (Ekinci, 2010). The effects of the school on the student should not be evaluated only in the classroom environment. The school has a multifaceted influence on the student. The school also provides a suitable environment for group interaction (Çiftçi, 2015).

Classroom management can be expressed as all the activities related to the systematic and conscious application of principles, concepts, theories, models and techniques related to the functions of planning, organization, application and evaluation in order to achieve the determined educational goals (Erdoğan, 2001). The most important element of the education system that affects the future life of the individual is the teacher. Classroom management can be summarized as the activities carried out by the teacher to create an environment that will facilitate and support academic and social-emotional learning (Evertson \& Weinstein, 2006). In another definition, classroom management is considered as the whole of the actions taken by the teacher to ensure classroom order, students' participation in the lesson and cooperation among students (Emmer \& Stough, 2001). The key to effective classroom management is considered to be the teacher's ability to increase the student's time spent working on academic activities and to minimize the time spent doing nothing or doing inappropriate work (Brophy, 1999). The teacher is the person who performs the teaching and is also effective in the development of the personality of the student (Özgan et al., 2011).

The importance of classroom management has been better understood with studies on student success, teacher competencies, and factors affecting teacher and student behaviors in relation to classroom processes. It can be said that the past experiences of teachers and students, social environment, family, education policies, education programs, teaching method techniques used by the teacher in the learning-teaching process and motivation are important factors in creating a positive classroom climate (Şişman and Turan, 2006).

Classroom management is generally thought of as providing discipline in the classroom (Üstün \& Eres, 2009; Üstün \& Demirbağ, 2003). In the classroom of a teacher who has effective classroom management strategies, problem behaviors are less and students' participation 
behaviors are more (Evertson, 1989; Evertson, Emmer, Sanford, \& Clements, 1983). The creation of an effective educational environment depends on the success of classroom management. For this reason, good classroom management constitutes the first step in achieving success in the field of education (Şentürk, 2010). However, today, classroom management includes not only ensuring the discipline of the teacher, who is the classroom manager, but also providing the physical order of the classroom environment, arranging the classroom communication, briefly providing a suitable environment for educational activities in the classroom (Seyfullahoğulları, 2010). There are many variables that affect classroom management. According to Özgan et al. (2011) classroom management in developed countries is not only focused on teachers. Creating quality education and training environments can be attributed to an effective school and classroom management, and an effective school and classroom management can be attributed to the presence of classroom management skills in teachers. Therefore, the quality of education largely depends on the quality of classroom management (Demirel, 2005). Classroom climate is an environment created by an effective teacher using various teaching strategies that he/she applies on time and in place. It can be said that the rules created to prevent disciplinary problems that may occur in the classroom climate are one of the most effective classroom methods (Emmer \& Evertson, 2012).

The most important element of classroom management is undoubtedly the teacher. From this point of view, the aim of this study is to examine the views of physical education teacher candidates on effective classroom management. For this purpose, answers to the following questions were sought;

1. According to physical education teacher candidates, what characteristics should teachers have in terms of effective classroom management?

2. According to physical education teacher candidates, how should students be motivated in classroom management?

3. According to the physical education teacher candidates, how should the teacher-student communication be in the classroom?

4. According to physical education teacher candidates, what should be done to improve teachers' classroom management skills?

5. According to physical education teacher candidates, how should unwanted student behaviors be managed in the classroom?

6. According to physical education teacher candidates, what should be done for an effective classroom management?

\section{METHOD}

Interview, one of the qualitative research methods, was used in the research. Qualitative research is a method that offers flexible action to the researcher compared to quantitative research, and offers different approaches to data collection method, analysis and research design (Gay, Mills, \& Airasian, 2006). Qualitative research is defined as research in which qualitative data collection methods such as observation, interview and document analysis are used, and a qualitative process is followed to reveal perceptions and events in a natural environment in a realistic and holistic way. Qualitative research is an approach that focuses on researching and understanding social phenomena in their environment with an understanding based on theory building (Yıldırım \& Şimşek, 2013). The research design is the Phenomenology design, which is one of the qualitative research designs. The phenomenology design focuses on phenomena that we are aware of but do not have an in-depth and detailed understanding of. In the study, the interview method was used as it would be effective in obtaining more detailed and detailed information about the views of physical education teacher candidates on classroom management, their approaches and their comments on definition. Unobservable phenomena such as experiences, attitudes, thoughts, intentions, comments, mental perceptions and reactions are tried to be understood through interviewing, which is a systematic data collection process determined by a research design (Yıldırım \& Şimşek, 2013). The interview method is prepared in order to get the same type of information from different people by focusing on similar issues (Yıldırım \& Şimşek, 2013).

Research Group: In the study, the views of physical education teacher candidates on effective classroom management were examined. For this purpose, the study group of the research consists of physical education teacher candidates studying at Iğdır University School of Physical Education and Sports. Maximum variation sampling, which is one of the purposive sampling methods, was used in the selection of the study group. According to Yıldırım and Şimşek (2013), the aim is to create a relatively small sample and to reflect the diversity of individuals who may be a party to the problem studied in this sample at the maximum level. The purpose of creating a sample based on maximum diversity is to try to find whether there are any common or shared phenomena among the various situations in order to generalize and to reveal the different dimensions of the problem according to this diversity (Yıldırım and Şimşek, 2013). The number of physical education teacher candidates in the sample group in this study was determined as 10 . The data about the research group are given in Table 1.

Table 1: Personal Characteristics of the Research Group ( $=10)$
\begin{tabular}{|l|l|l|l|}
\hline Variables & Groups & $\mathbf{n}$ & $\%$ \\
\hline \multirow{3}{*}{ Gender } & Male & 7 & 70 \\
\cline { 2 - 4 } & Woman & 3 & 30 \\
\hline \multirow{5}{*}{ Class } & 1 & 3 & 20 \\
\cline { 2 - 4 } & 2 & 2 & 20 \\
\cline { 2 - 4 } & 3 & 3 & 30 \\
\cline { 2 - 4 } & 4 & 2 & 30 \\
\hline
\end{tabular}

Tablo 1 incelendiğinde katılımcıların \%70'i erkek beden eğitimi öğretmeni adayı, \%30'u ise kadın beden eğitimi öğretmeni adayından oluşmaktadır. Buna göre katılımcıların çoğunluğu erkek beden eğitimi öğretmeni adayından oluşmaktadır. Katılımcıların öğrenim gördükleri sınıfı incelediğimizde; \%30'u 1, \%20'si 2, \%30'u 3, \%20'si ise 4. sınıfta öğrenim görmektedir.

Preparation and Application of the Open-Ended Questionnaire: In the research, a semi-structured interview form consisting of 6 items was used to collect 
qualitative data. Through the interview technique, which is frequently used in qualitative research, the researcher tries to understand unobservable situations such as attitudes, experiences, intentions, thoughts, mental perceptions, comments and reactions (Yıldırım \& Şimşek, 2013). In order to prepare the interview form, a comprehensive literature review was conducted and the interview form was prepared. While preparing the semi-structured interview form, which is used as a data collection tool, a field survey was first conducted by the researcher and a semistructured interview form question pool was created, which includes questions that can be asked to physical education teacher candidates regarding the subject. Then, the questions created by three experts were examined and the semi-structured interview form was finalized. None of the participants included in the study were compelled to participate in the research, and the principle of confidentiality was meticulously complied with during the application and collection of the questionnaires. In the research, interviews were conducted with 10 volunteer physical education teacher candidates studying at Iğdır University School of Physical Education and Sports, using a semi-structured interview form. The interviews were recorded with a voice recorder and then these recordings were transcribed.

Analysis of Data: The data obtained from the interview form used in the research were recorded with a voice recorder. After the application, the qualitative data in the audio recordings containing the answers of the security forces were transferred to the computer environment by the researcher. Then, qualitative data were analyzed by content analysis method. Content analysis technique, which is frequently used, was used in the analysis of the data obtained from the questions in the interview form. The aim is to reach concepts that can explain the collected data (Yıldırım and Şimşek, 2013).

\section{FINDINGS AND COMMENT}

In this section, there are findings related to the data obtained after the interviews with the working group.

Table 2. Distribution of the participants' views on what characteristics teachers should have in terms of effective classroom management.

\begin{tabular}{|l|l|l|}
\hline Themes & $\mathbf{n}$ & $\%$ \\
\hline Must be proficient in the field & 9 & 15.4 \\
\hline Must love his job & 8 & 13.6 \\
\hline Must have effective communication skills & 8 & 13.6 \\
\hline Must have an innovative personality & 8 & 13.6 \\
\hline Must know the student well & 7 & 11.8 \\
\hline Must be patient & 7 & 11.8 \\
\hline Should be equal and fair & 6 & 10.1 \\
\hline Must be able to empathize & 6 & 10.1 \\
\hline Total & $\mathbf{5 9}$ & $\mathbf{1 0 0}$ \\
\hline
\end{tabular}

When the views of the physical education teacher candidates participating in the research are examined in Table 2, for an effective classroom management; $15.4 \%$ stated that they should be competent in their field, $13.6 \%$ should love their profession, $13.6 \%$ should have effective communication skills and $13.6 \%$ should have an innovative personality. In addition, some of the physical education teacher candidates participating in the research, in terms of effective classroom management; They stated that it is necessary to know the student well, to be patient, to be equal and fair, and to be able to empathize.

Table 3. Distribution of the participants' views on how students should be motivated in classroom management.

\begin{tabular}{|l|l|l|}
\hline Themes & $\mathbf{n}$ & $\%$ \\
\hline By loving the lesson & 9 & 19.6 \\
\hline Loving the teacher & 9 & 19.6 \\
\hline Giving responsibility to the student & 8 & 17.3 \\
\hline $\begin{array}{l}\text { Determining the classroom rules together } \\
\text { with the student }\end{array}$ & 7 & 15.2 \\
\hline By applying different teaching methods & 7 & 15.2 \\
\hline $\begin{array}{l}\text { Paying attention to the different views of } \\
\text { students }\end{array}$ & 6 & 13.1 \\
\hline Total & $\mathbf{4 6}$ & $\mathbf{1 0 0}$ \\
\hline
\end{tabular}

When the views of the physical education teacher candidates participating in the research on how the students should be motivated in classroom management in Table 3, $19.6 \%$ of them came to the forefront by making the lesson and the teacher popular. In addition, the research group; They stated that they would motivate students by giving responsibility to the student, determining the classroom rules together with the student, and applying different teaching methods. In addition, some of the physical education teacher candidates participating in the research, $13.1 \%$, stated that they would motivate the students by giving importance to the different opinions of the students.

Table 4. Distribution of the participants' views on how teacher-student communication should be in the classroom.

\begin{tabular}{|l|l|l|}
\hline Themes & N & $\%$ \\
\hline Creating a democratic environment & 8 & 23.6 \\
\hline Ensuring student participation in the lesson & 7 & 20.6 \\
\hline Collaboration between teacher and student & 7 & 20.6 \\
\hline By doing group work & 6 & 17.6 \\
\hline Making the teaching environment effective & 6 & 17.6 \\
\hline Total & $\mathbf{3 4}$ & $\mathbf{1 0 0}$ \\
\hline
\end{tabular}

In Table 4, when the views of the physical education teacher candidates participating in the research on how teacher-student communication should be in the classroom; $23.6 \%$ of them stated that by creating a democratic environment, $20.6 \%$ of them stated that communication would be ensured by ensuring the participation of the student in the lesson and cooperation between the teacher and the student. In addition, $17.6 \%$ of the physical education teacher candidates participating in the research stated that communication would be achieved by doing group work and making the teaching environment effective.

Table 5. Distribution of the participants' views on what needs to be done in order to improve their classroom management skills.

\begin{tabular}{|l|l|l|}
\hline Themes & N & $\%$ \\
\hline To gain professional skills & 9 & 22.5 \\
\hline Implementation skills & 8 & 20 \\
\hline Gaining effective communication skills & 8 & 20 \\
\hline Gain skills in the field & 8 & 20 \\
\hline To gain the ability to use technology effectively & 7 & 17.5 \\
\hline Total & $\mathbf{4 0}$ & $\mathbf{1 0 0}$ \\
\hline
\end{tabular}


When the views of the physical education teacher candidates participating in the research on what needs to be done in order to improve their classroom management skills are examined in Table $5,22.5 \%$ of them stated that it is necessary to gain professional skills. In addition, $20 \%$ of the physical education teacher candidates stated that it is necessary to gain practical skills, gain effective communication skills and gain skills related to their field. In addition, physical education teacher candidates; They expressed the opinion that in order to develop classroom management skills, it is necessary to gain the ability to use technology effectively.

Table 6. Distribution of the participants' views on how undesirable student behaviors should be managed in the classroom.

\begin{tabular}{|l|l|l|}
\hline Themes & N & $\%$ \\
\hline By giving responsibility & 9 & 26.5 \\
\hline By planning the lesson together & 7 & 20.6 \\
\hline By warning & 7 & 20.6 \\
\hline Giving rewards and punishments & 6 & 17.6 \\
\hline I will direct you to the counseling service & 5 & 14.7 \\
\hline Total & $\mathbf{3 4}$ & $\mathbf{1 0 0}$ \\
\hline
\end{tabular}

When the views of the physical education teacher candidates participating in the research on how to manage unwanted student behaviors in the classroom are examined in Table 6, 26.5\% of them expressed the opinion that undesirable behaviors can be managed by giving responsibility, and $20.6 \%$ by planning and warning the lesson together. In addition, some of the physical education teacher candidates participating in the research stated that their unwanted behaviors can be managed by giving rewards and punishments and directing them to the guidance service.

Table 7. Distribution of the participants' views on what should be done for an effective classroom management.

\begin{tabular}{|l|l|l|}
\hline Themes & N & $\%$ \\
\hline Giving the student a task and responsibility & 9 & 12.2 \\
\hline Getting to know the student well & 9 & 12.2 \\
\hline Communicating well with the student & 9 & 12.2 \\
\hline Valuing the student & 8 & 10.8 \\
\hline Interested and willing & 8 & 10.8 \\
\hline $\begin{array}{l}\text { Taking into account the individual differences } \\
\text { of students }\end{array}$ & 7 & 9.4 \\
\hline $\begin{array}{l}\text { By making the student more active in the } \\
\text { lesson }\end{array}$ & 7 & 9.4 \\
\hline By gaining dominance in the classroom & 6 & 8.1 \\
\hline By providing school-teacher-family cooperation & 6 & 8.1 \\
\hline Emphasizing the question-answer method & 5 & 6.8 \\
\hline Total & $\mathbf{7 4}$ & $\mathbf{1 0 0}$ \\
\hline
\end{tabular}

When the opinions of the physical education teacher candidates participating in the research on what should be done for an effective classroom management are examined in Table $7,12.2 \%$ of them stated that an effective classroom management can be done by assigning duties and responsibilities to the student, knowing the student well and establishing healthy communication with the student. In addition, physical education teacher candidates participating in the research; He expressed an opinion that an effective classroom management would be achieved by valuing the student, being interested and willing to the lesson, taking into account the individual differences of the students and making the student more active in the lesson. Some of the participants in the research are; He stated that an effective classroom management would be achieved by providing dominance in the classroom, providing schoolteacher-family cooperation and giving weight to the question-answer method.

\section{DISCUSSION AND CONCLUSION}

In this part of the research, the results obtained depending on the findings obtained with the aim of examining the opinions of physical education teacher candidates on effective classroom management are given.

When the opinions of the physical education teacher candidates participating in the research on what characteristics teachers should have for an effective classroom management; It has been seen that he should be sufficient in his field, love his profession, have effective communication skills and have an innovative personality. In addition, physical education teacher candidates participating in the research, in terms of effective classroom management; They stated that they should know the student well, be patient, be equal and fair, and have the ability to empathize. From this point of view, in line with the opinions of physical education teacher candidates, in terms of effective classroom management; we can say that he should value his profession, have sufficient knowledge about his field and have high communication skills, as well as have an innovative and progressive personality. Yeşilyurt and Çankaya (2008), stated in their study that teachers should educate themselves in terms of knowledge and skills, and that they should be sufficient in terms of profession and field knowledge. Kaya (2010), stated that the teacher's creating a positive classroom climate in the classroom and establishing a healthy communication with the students will enable the students to actively participate in the lesson.

When the opinions of the physical education teacher candidates participating in the research on how the students should be motivated in classroom management were examined, it came to the fore that it was necessary to endear the lesson and the teacher. In addition, it has been observed that some of the physical education teacher candidates participating in the research will motivate students by giving responsibility to the student, determining the classroom rules together with the student and applying different teaching methods, while some of them will motivate the students by giving importance to the different views of the students. In line with the opinions expressed by the physical education teacher candidates; We can say that we can motivate students by making the lesson more effective, making the teacher love it, determining the classroom rules together and giving the student responsibility at different times. Paliç and Keleş (2011), stated in their study on primary and secondary school teachers that teachers have communication skills, content knowledge, professional experience and planning in relation to the professional characteristics category. These features, stated by the research group, are among the "general competencies of the teaching profession" adopted by the Ministry of National Education (MEB, 2004). Çakmak, Kayabaşı and Ercan (2008), Kahyaoğlu and Yang (2007), stated in their studies that making the lesson more 
interesting by using different teaching methods will increase the efficiency.

When the opinions of the physical education teacher candidates participating in the research on how teacherstudent communication should be in the classroom, the majority of them; it was seen that they expressed their opinion that communication would be ensured by creating a democratic environment, ensuring student participation in the lesson and cooperation between teacher and student. In addition, physical education teacher candidates; They stated that effective communication would be achieved by doing group work and making the teaching environment effective. Therefore, in line with the opinions of the research group, on providing effective communication between the teacher and the student in the classroom; It can be said that student participation in the lesson should be ensured and cooperation between teacher and student should be established. Studies have shown that the way to achieve success in education is based on an effective and quality classroom management (Erginbaş, 2009; Uludağ \& Odacı, 2002; Öğilme \& Özdemir, 1995). Kubat (2016), stated in his study that students should take an active role in the learning and teaching process.

When we look at what needs to be done in order to improve the classroom management skills of the physical education teacher candidates participating in the research; The need to gain professional skills was highlighted. In addition, physical education teacher candidates in order to improve their classroom management skills; They stated that it is necessary to gain application skills, to gain effective communication skills, to gain skills related to the field and to gain the ability to use technology effectively. From this point of view, we can say that physical education teacher candidates should gain practical skills related to their field and daily life and have effective communication skills in order to improve their classroom management skills.

When we look at the opinions of the physical education teacher candidates participating in the research on how to manage unwanted student behaviors in the classroom, almost all of them stated that $26.5 \%$ of them gave the responsibility to the student, and $20.6 \%$ of them stated that undesirable behaviors can be managed by planning the lesson together with the student and warning the student. In addition, some of the physical education teacher candidates participating in the research stated that undesirable behaviors can be managed by giving rewards and punishments to the student or directing them to the guidance service. Based on these considerations, we can say that, in general, we need to give responsibility to the student or plan the lesson together with the student in order to effectively manage undesirable student behaviors in the classroom. Sueb (2013), stated in his study that he applied the reward and punishment system while providing in-class authority.

When we look at the opinions of the research group on what should be done for an effective classroom management; It has been revealed that an effective classroom management can be done by assigning duties and responsibilities to the student, knowing the student well and establishing healthy communication with the student. Some physical education teacher candidates participating in the research; He expressed an opinion that an effective classroom management would be achieved by valuing the student, being interested and willing to the lesson, taking into account the individual differences of the students and making the student more active in the lesson. In addition, some participants; He stated that an effective classroom management would be achieved by providing dominance in the classroom, providing school-teacher-family cooperation and giving weight to the question-answer method. Şentürk (2007), states in his study that for a successful education and training, teachers should take into account the individual differences of students. It is stated that by arranging the time allocated for learning according to the individual needs of the students, more learning opportunities can be provided for each student (Gökçe, 2014).

As a result, physical education teacher candidates stated that for an effective classroom management, teachers should be competent in their field and do their job lovingly. The physical education teacher candidates participating in the research came to the forefront by endearing the lesson and the teacher. In addition, the research group; They stated that they would motivate students in classroom management by giving responsibility to the student, determining the classroom rules together with the student, and applying different teaching methods. In addition, in order for the student-teacher communication of the research group to be effective; They expressed their opinion that a democratic environment should be created and cooperation between the parties should be ensured. In addition, in terms of improving the classroom management skills of the research group; In addition to gaining professional skills and practice skills, while managing unwanted student behaviors in the classroom; They stated that it is necessary to give responsibility to the student and to plan the lesson together with the student. At the same time, for an effective classroom management; It has been concluded that an effective classroom management can be done by knowing the student well and establishing healthy communication with the student.

\section{REFERENCES}

1. Brophy, J. (1999). Perspectives of classroommanagement: Yesterday, today, andtomorrow. In H. JeromeFreiberg (Ed.), Beyond behaviorism: Changing the class management paradigm(pp. 43-56). Needham Heights, MA: Allynand Bacon.

2. Cakmak, M., Kayabaşı, Y., Ercan, L. (2008). Pre-service Teachers' Views on Classroom Management Strategies. Hacettepe University Faculty of Education Journal, 35(1):5364.

3. Çiftçi, A.S. (2015). The Relationship Between Primary School Teachers' Classroom Management Styles and Their Views on Democratic Values. Çanakkale Onsekiz Mart University, Institute of Educational Sciences, Master Thesis, Canakkale.

4. Demirel, Ö. (2005). Planning and evaluation in teaching: The art of teaching. Ankara: Pegem A Publications.

5. Ekinci, A. (2010). Opinions of Principals and Teachers Working in Primary Schools on their Professional Problems. Elementary Education Online, 9(2):734-748.

6. Emmer, E., Evertson, C. (2012). Classroom Management For Middle and High School Teacher (8Th edition). UpperSaddleRiver, NJ, USA; Merrill/Prenticehall. 
7. Emmer, E.T., Stough, L.M. (2001). Classroom management: A critical part of education. Educational Psychologist, 36(2):103-112.

8. Erdoğan, İ. (2001). Classroom Management. Contact. Ankara: Sistem Publishing.

9. Erginbaş, Ş. (2009). The Effectiveness of Technology Supported Mathematics Teaching and Classroom Management in Terms of Student Characteristics. Süleyman Demirel University, Institute of Science and Technology, Master's Thesis, Isparta.

10. Evertson, C.M. (1989). Improving elementary classroom management: A school based training program for beginning the year. Journal of Educational Research, 83(2):82-90.

11. Evertson, C.M., Emmer, E.T., Sanford, J.P., Clements, B.S. (1983). Improving classroom management: An experiment in elementary school classrooms. The Elementary School Journal, 84(2), 173-188.

12. Evertson, C.M., Weinstein, C.S. (2006). Classroom management as a field of ınquiry. Evertson, C.M., Weinstein, C.S. (Ed.), Handbook of classroom management: Research, practice and contemporary issues, 3-15. Lawrence Erlbaum Associates, Inc.

13. Gay, L., Mills, G., Airasian, P. (2006). Educational Research: Competencies For Analysis and Application (8th ed.). New York: Prentice Hall.

14. Gökça, F. (2014). Management of Learning and Teaching Process in the Classroom. Ankara: Pegem Academy.

15. Kahyaoğlu, M., Yangın, S. (2007). Views of Primary Education Teacher Candidates on their Professional SelfEfficacy. Kastamonu Journal of Education, 15(1):73-84.

16. Kaya, Z. (2010). Classroom Management. (10 Prints). Ankara: Pegem Academy.

17. Kubat, U. (2016). Determination of Science Teacher Candidates' Views on Effective Classroom Management. Journal of Academic Social Research, 4(36):628-640.

18. MEB. (2004). General Competencies of Teaching Profession. http://otmg.meb.gov.tr/ Yet Genel.html, retrieved on 10/6/2010.

19. Öğülmüş, S., Özdemir, S. (1995). The Effect of Class and School Size on Students. Educational Management in Theory and Practice, (1)2:261-271.
20. Özgan, H., Yiğit, C., Aydın, Z., Küllük, M. (2011). Examination and Comparison of Primary School Teachers' Perceptions on Classroom Management. Journal of Social Sciences, 10(1):617-635.

21. Paliç, G., Keleş, E. (2011). Teachers' Views on Classroom Management. Educational Management in Theory and Practice, 17(2):199-220.

22. Seyfullahoğulları, A. (2010). A Research on Teacher's Approach to Classroom Problems Encountered in the Management of Large Classrooms in Primary Schools. Journal of Mustafa Kemal University Institute of Social Sciences, 7(14):21-40.

23. Sueb, R. (2013). Pre-service teachers' classroom management in secondary school: Managing for success in teaching and learning. Procedia-Socialand Behavioral Sciences, 90(1):670-676.

24. Şentürk, E. (2010). Investigation of Teachers' Attitudes towards Undesirable Student Behaviors Observed in the Classroom in Primary Schools in Terms of Some Variables, Yüzüncü Yıl University, Institute of Social Sciences, Master Thesis, Van.

25. Şentürk, H. (2007). Classroom Management Approaches of Counselors in Practice High Schools. Journal of Dicle University Ziya Gökalp Education Faculty, 8(1):7-16.

26. Şişman, M., Turan, S. (2006). Classroom Management. (4th Edition). Ankara: Doctary Publishing.

27. Uludağ, Z., Odacı, H. (2002). Physical Space in Educational Activities. Journal of National Education, Issue 153-154:1836.

28. Üstün, A., Demirbağ, H. (2003). Democratic Discipline in the Classroom. Educational Studies, 3 (11):87-95.

29. Üstün, A., Eres, F. (2009). Disciplinary Problems in Secondary Education: A Sample of Amasya. Proc. Social and Behavioral Sciences, 1(1):1717-1725.

30. Yeşilyurt, E., Çankaya, İ. (2008). Determination of Teacher's Qualifications in terms of Classroom Management. Electronic Journal of Social Sciences, 23(1):274-295.

31. Yıldırım, A., Şimşek, H. (2013). Qualitative Research Methods in The Social Sciences. (9th Edition). Ankara: Seçkin Publishing House. 